\title{
Article \\ The Inter-Relationship between CSR, Inclusive Leadership and Employee Creativity: A Case of the Banking Sector
}

\author{
Muhammad Sanaullah Shah ${ }^{1, *(\mathbb{D})}$, Cisheng $\mathrm{Wu}^{1}$ and Zia Ullah ${ }^{2}$ (I) \\ 1 School of Management, Hefei University of Technology, Hefei 230009, China; cswu@hfut.edu.cn \\ 2 Leads Business School, Lahore Leads University, Lahore 54000, Pakistan; chairperson.ba@leads.edu.pk \\ * Correspondence: sanaullahabidi@yahoo.com
}

check for

updates

Citation: Shah, M.S.; Wu, C.; Ullah, $Z$. The Inter-Relationship between CSR, Inclusive Leadership and Employee Creativity: A Case of the Banking Sector. Sustainability 2021, 13, 9158. https://doi.org/

$10.3390 /$ su13169158

Academic Editors: Seung-Wan Kang, Seung Yeon Son and Eunmi Jang

Received: 8 July 2021

Accepted: 6 August 2021

Published: 16 August 2021

Publisher's Note: MDPI stays neutral with regard to jurisdictional claims in published maps and institutional affiliations.

Copyright: (c) 2021 by the authors. Licensee MDPI, Basel, Switzerland. This article is an open access article distributed under the terms and conditions of the Creative Commons Attribution (CC BY) license (https:// creativecommons.org/licenses/by/ $4.0 /)$.

\begin{abstract}
The stiff situation of competitiveness in every industry has posed some serious challenges for businesses all over the world. Thus, every segment of the business is realizing the importance of creativity to remain alive in a cut-throat competitive environment. However, the banking sector has not received due attention in this regard. To bridge this gap, the current study was carried out to explore the relationship of employees' perception of corporate social responsibility (CSR) of their bank and employee creativity with the mediating effect of inclusive leadership (IL). The data for the current study were collected from the banking sector of Pakistan through a self-administered questionnaire $(n=533)$ and were analyzed by using structural equation modeling (SEM) in AMOS. The statistical findings of the current survey validate the direct relationship between CSR and employee creativity. The results also confirm the mediating effect of IL in this relationship. The findings of the current survey will help policymakers from banking institutions to improve their understanding of CSR. Furthermore, these findings will help policymakers to embrace employee creativity as a "new normal" for this sector.
\end{abstract}

Keywords: corporate social responsibility; employee creativity; inclusive leadership; extra-role behavior; bank

\section{Introduction}

The current era characterized by digitalization, globalization, and a stiff situation of competitiveness in almost every business sector has posed significant challenges for corporations to remain alive in their respective industries. Therefore, to remain competitive, the need for a corporation to be creative is increasing [1]. As argued by Drucker [2], the inability of a corporation towards creativity can be a stepping stone for its downfall. The same argument was presented by Na et al. [3], as they acknowledged the important role of creativity and innovation for sustainable competitive advantage. Perhaps this is one of the underlying reasons that a recent surge in the related literature on the topic of creativity and innovation is evident [4-7]. Contemporary businesses are searching for effective ways of creativity. In this regard, it is very recently in the literature that the role of employees, as a source of creativity in a corporation, has been recognized by various scholars. For instance, Sarfraz et al. [8] noted the importance of employee creativity in the context of the police department of Pakistan. They further noted that in the presence of an authentic leader, the employees are encouraged to perform creative tasks. Likewise, Imam et al. [9] posited the importance of employee creativity to better survive and compete in the context of the telecom sector. They further emphasized that when appropriate leadership exists in an organization, employee creativity is fostered. The same findings were shared by Tong et al. [10], who referred to employee creativity as an important factor for organizational performance by stressing that positive CSR perceptions of employees about their organization shape their creative capability.

However, it is still vague in the literature what are the critical factors that urge employees to engage in creative tasks. In this regard, various scholars have identified different 
factors that influence employee creativity. For instance, in their seminal work, Scott and Bruce [11] identified organizational culture as an important factor to predict employee creativity. Likewise, Kim and Lee [12] proposed knowledge sharing as an enabler for creativity. Volmer et al. [13] were convinced that job autonomy and organizational culture are critical factors for employee creativity while Nazir and Islam [14] proposed that employees' corporate social responsibility (CSR) perception of their corporation is the most convincing factor to explain employee creativity. Quite recently, CSR has been acknowledged as a strategic enabler to shape the creative capability of employees. The underlying reason for this argument lies in the fact that when an organization engages itself in different CSR activities, this gives a sense of care and responsibility for different stakeholders. Employees of such organizations observe this commitment of their organization for the betterment of all stakeholders including employees, customers, society, and the environment and they are self-motivated to support their organization. Thus, they not only perform their formal job obligations, but also go beyond one step further by engaging themselves into different extra-roles to foster the overall performance of their organization. Among such extra-roles is employee creativity. In this context, different research studies were carried out to explore the relationship between CSR and employee creativity [4,15-17]. However, studies have produced mixed findings, implying that there is a need to conduct more research in this area. Therefore, one of the objectives of the current study is to explore the relationship between CSR and employee creativity.

Corporations need leaders to get work done by the employees. In the absence of effective leadership, there is a strong likelihood that an organization will not be in a position to achieve its objectives. This line of reasoning can be seen in the path-breaking work of Katz [18], who mentioned that corporations require leaders who can motivate the workforce to induce positive behavior. Since then, different scholars have acknowledged the importance of effective leadership to explain positive employee behavior, for example, employee commitment [19], engagement [20], motivation [21], and satisfaction [22]. In this context, the role of an appropriate leadership style such as inclusive leadership (IL) in influencing employee creativity has been under-explored in the prior literature. Although there have been some studies highlighting the importance of leadership to predict employee creativity-for instance, a recent study by Asif et al. [23], emphasized the importance of ethical leadership to foster employee creativity in the context of the Chinese public sector organizations-the importance of IL in fostering employee creativity has not been well explored in the preceding literature. Moreover, the mediating role of IL in the relationship between CSR and employee creativity has not been known in preceding studies. The authors argue here that though the direct role of leadership in fostering employee creativity is pre-established in the literature, it is also important to investigate the mediating effect of leadership in shaping the creative capability of followers. The reason for this argument lies in the fact that corporate leaders are the figures that work as a bridge between organization and employees. In the presence of an effective leader, the relationship between an organizational strategy (CSR in the current case) and employee performance (employee creative performance) is well explained. Therefore, another important objective of this analysis is to explore the mediating effect of IL on the relationship between CSR and employee creativity.

Prior studies have recognized the importance of an inclusive leader in positively influencing employee creativity. An inclusive leader is one who promotes openness at the workplace and encourages the followers to share their novel ideas with their leader in order to foster the overall organizational performance [24]. Moreover, an inclusive leader creates an environment in which employees feel that their leader is available to them all the time and pays significant attention to fulfilling the needs of the employees [25]. Therefore, organizations need IL to support the creative process on the part of the employees. On the other hand, the CSR orientation of a socially responsible organization creates a sense of psychological safety, transparency, and a sense of caring among employees. In a nutshell, employees' CSR perception of their organization creates a sense of caring among employees and an inclusive leader encourages the sense of openness on the part of employees, thus 
employees are willfully engaged in different creative tasks. However, the importance of CSR in the mediating effect of IL has not been explored in the banking context of a developing country (Pakistan) which provides a considerable gap for research to be conducted in this area. Therefore, the current study investigated the relationship between CSR and employee creativity with the mediating effect of IL in the banking sector of Pakistan.

Overall, the current study offers some important contributions to the existing literature. Firstly, the current study is one of the few studies that attempt to investigate and offer comprehensive knowledge related to CSR and IL which encourage employees to be more creative and to perform a job task in a novel way. Secondly, the current study adds to the available literature by introducing IL as a mediating variable, whereas most of the previous studies have investigated the direct impact of IL on employee creativity. Thirdly, the current study enriches the current domain of employee creativity in the context of the banking sector, whereas in prior studies this sector was less considered as a relative sector for employee creativity due to the fact that banking operations are performed in a tightly monitored environment with very little room is available for creativity. Fourthly, the current study is carried out in Pakistan, which is a developing economy, whereas most of the prior studies considered developed countries' sectors for employee creativity. Last but not least, the current study identifies different practical implications for the banking sector of Pakistan to realize the importance of effective leadership that can develop a work environment in which employees are encouraged to perform their work-related tasks in a creative way.

\section{Theoretical Framework and Hypotheses}

The current study employs social exchange theory (ST) to explain the proposed relationship and hypotheses. ST was proposed by Homans [26] who mentioned that social exchange in an organizational context happens on two grounds: economic exchange and social exchange. While the economic exchange between employee and organization is concerned with economic benefits specified in a formal job contract, the social exchange is a purely unspecified obligation between employee and employer [27]. Of a direct relevance in the current context, ST provides a base to understand the relationship between CSR and employee engagement in different extra-roles in a way in which employees see that their organization is socially responsible and takes care of the society; it infuses in them a positive feeling. Further, as this commitment towards society is an extra-role commitment of an organization, the employees are instigated to help their socially responsible organization by engaging themselves in different extra roles. This line of reasoning is also evident in the work of Organ [28]. Specifically, employee creativity is also an extra-role behavior that is also linked as an outcome of an organization's CSR engagement [4,15]. More specifically, different authors have also pointed out that the values of a socially responsible organization are congruence with employees' personal values and thus they are comfortable serving such organizations [29] and are expected to happily perform different extra-roles.

The current study uses the CSR definition of World Business Council for Sustainable Development [30] which posited that CSR is an extra-role commitment of a business towards sustainable development by considering employees, local communities, the environment, and other stakeholders. The available literature on ethics makes it evident that the ethical context of an organization is related to positive employee behavior. In recent years, CSR has emerged as an important business imperative for all segments [31]. Of more relevance, scholars have argued that employees' CSR perception of their organization is positively linked with their creative capability [32,33]. In fact, Pandey and Gupta [34] called it the "spiritual consciousness" of employees that leads them to be engaged in extra-roles as a result of the CSR commitment of an organization. A socially responsible organization builds a work environment that is characterized by a sense of caring for all stakeholders. The employees in this context are expected to reciprocate their organization positively, and thus they are expected to go beyond their formal job obligation to support their organization. Brammer et al. [35] mentioned that an employee's CSR perception of 
his or her organization builds a feeling of meaningful work which enhances employee creativity capability. Moreover, a CSR-oriented organization attempts to develop a flexible work environment that urges the employees to be engaged in different creative tasks as contrasted by a rigid work environment in which employees are strictly required to stick with specific tasks. Different scholars have recently linked CSR with employee creativity, such as the contributions from Kim et al. [36], Bibi et al. [37], and Nazir and Islam [38]. To conclude, ST suggests a reason why employees of a socially responsible organization feel positive about their organization. In fact, the employees feel that their organization is benefitting all stakeholders through its CSR orientation. Employees are also important stakeholders and they are expected to reciprocate positively the benefits of their organizations due to its engagement in different CSR activities [39]. Relationships in organizations often involve exchanges of symbolic and intangible resources [27] which is referred to as 'norm of reciprocity' as indicated by Gouldner [40] that ultimately leads employees' extra-role behavioral intentions to produce benefits for an organization. Similarly, as socially exchanged relationships between employees and organization are based on trust and mutual expectations, there is strong case that these relationships will be exchanged positively over time. Therefore, the following hypotheses are suggested:

Hypothesis 1 (H1). CSR perception of employees is positively linked with their creative capability.

Another critical imperative of an organization is to develop an effective leadership that is able to get work done by the employees. In the current context, a socially responsible organization is expected to give rise to a leadership model which is flexible and caring toward the workforce [41]. In an organization that cultivates a culture of CSR, a leader with inclusive behavior is very important to setting the organizational tone to be perceived as a socially responsible organization by the employees [42]. Corporate leaders are treated as a valued resource in a socially responsible organization. This valued treatment of corporate leaders is something that turns them into happy leaders and they willingly promote a flexible and ethical climate among their followers while working for a socially responsible organization [43,44]. Thus, engaging leadership effective in achieving corporate objectives is the hallmark of a socially responsible organization [45]. Different researchers have argued about the direct association between CSR and the inclusive behavior of a leader $[46,47]$. To conclude, CSR as a business imperative can generate real consequences for various stakeholders by implementing ethical values and sustainable work practices in an organization. This notion of a socially responsible organization to work in the larger interest of society and the environment is transmitted to the corporate leaders and they, following ST in turn, exchange this CSR orientation of an organization with the followers. Consequently, corporate leaders are expected to be engaged in ethical practices. The above arguments encourage the authors to formulate the following hypothesis:

\section{Hypothesis 2 (H2). CSR is positively linked with inclusive leadership.}

Leadership is assumed to be a critical factor to fostering employee creativity, as acknowledged by various scholars [5,36]. Recently, IL has been recognized as an emerging leadership style to explain employee creativity due to specific reasons. Firstly, an inclusive leader is one who manifests openness [25] and thus encourages the followers (employees in the current case) to complete different tasks in creative manners. Secondly, an inclusive leader provides necessary support to the followers to enhance their creative capability at the workplace; for example, he or she provides the followers with organizational resources, information, and time to cultivate creative endeavors [48]. Thirdly, an inclusive leader is expected to stimulate and invigorate his followers to be more involved in creative tasks [49]. Last but not the least, inclusive leaders provide relational support to the followers which is very important for followers to enhance their creative capability [50]. The notion of inclusive leadership was introduced in the business study by Nembhard and Edmondson [51], who posited it as the responsibility of a leader to appreciate the 
contribution of the followers at all levels in an organization. Specifically, Hollander [52] argued that an inclusive leader creates a win-win situation for an organization by promoting a common vision based on the interdependent relationship with the followers. More specifically, inclusive leadership is assumed to tolerate the errors of the followers and encourage them by providing appropriate support and guidance. This argument can be seen in the work of Qi, Liu, Wei and Hu [50] who posited that an inclusive leader not only tolerates the errors of followers but also listen to their alternative opinions in how to perform a task creatively. Thus, contrasted by other styles of leadership, an inclusive leader promotes openness, belongingness, interdependence and above all, inclusiveness in an organization. All these factors are important to fostering employee creativity, as documented by Randel et al. [53]. Inclusive leadership has significantly entered into the lexicon of ST as different scholars have explained inclusive leadership and employee through the lens of this theory [54,55]. Specifically, Qi, Liu, Wei and Hu [50] were convinced of the importance of this theory to explain employee creativity.

Corporations craft different strategies but in order to implement these strategies well, the corporations need corporate leaders. In other words, leaders work as a bridge between organizations and employees. An organization may craft better CSR strategies, but to receive an effective response for such strategies from employees, the intervention of an effective leadership style is a prerequisite. Different scholars have argued that in the presence of effective leadership, the likelihood for an organization achieving its objective is high [56,57]. An inclusive leader shows supportive behavior towards employees which is characterized by availability and openness. This supportive notion of behavior is infused positively among the employees and they feel comfortable sharing their creative ideas with their leader. In fact, Carmeli, Reiter-Palmon and Ziv [25] found that IL strengthens employees' psychological safety, which in turn encourages them to be involved in creative tasks. Moreover, in line with ST, an inclusive leader pays extra attention to the needs and interests of the followers, which is taken positively by the followers and in return, they also show extra interest in performing different discretionary roles, including creativity. Moreover, ST suggest that the extra support that is given by an inclusive leader to the employees is perceived as 'favorable treatment' that ultimately encourages them to act favorably for their leader and the organization.

In the context of the current study, an inclusive leader helps the followers to clearly understand an organization's CSR approach for the betterment of the community and other stakeholders. Moreover, an inclusive leader encourages a follower at every level of the organization to realize his creative potential [58]. Generally, it is established in the literature that in the presence of effective leadership, the relationship between CSR and employees' behavior is better explained $[29,59]$. To conclude, an organizations' CSR engagement positively influences employee creativity and the presence of an inclusive leader explains this relationship in a clearer way. The above discussion paves the way for authors to frame the following hypotheses along with the proposed conceptual model (Figure 1):

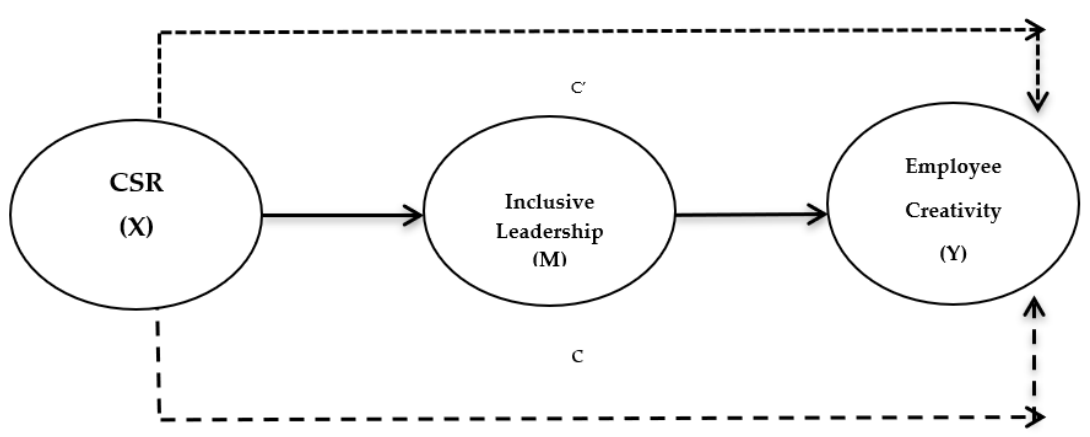

Figure 1. Research model of the current analysis: CSR $(X)=$ the input variable, creativity $(Y)=$ the outcome variable, inclusive leadership $(\mathrm{M})=$ the intervening variable, $\mathrm{C}=$ the effect of $\mathrm{X}$ on $\mathrm{Y}$ in the absence of $\mathrm{M}, \mathrm{c}^{\prime}=$ effect of $\mathrm{X}$ on $\mathrm{Y}$ in the presence of $\mathrm{M}$. 
Hypothesis 3 (H3). Inclusive leadership is positively related to employee creativity.

Hypothesis 4 (H4). The relationship between CSR and employee creativity is mediated by inclusive leadership.

\section{Methodology}

The banking sector of Pakistan was the target sector for the current survey which is divided into two major streams: the conventional banking stream and the Islamic banking stream. The sector is dominated by conventional banks that constitute more than $80 \%$ of the total industry [60]. The basic distinction between the two banking systems is the intervention of interest. The conventional banking system follows standardized interest-based banking operations while the Islamic banking structure operates under the philosophy of interest-free banking. The currents study considered four major banks (Habib bank limited-HBL, National bank of Pakistan-NBP, United bank limited-UBL, and Allied bank limited-ABL) in the country. These banks were actively involved in different CSR activities as verified by the authors by paying personal visits and observing the web pages of these banks. Yet another reason for selecting these banks lies in the fact that these banks are present in every corner of the country. Therefore, the selection of these banks, to represent the banking sector, seems logical. Mainly, the authors collected the data from two large cities of Pakistan (Lahore and Islamabad). These two cities contain multiple banking branches of these banks. The authors think it important to mention here that the data for the current survey were collected from these two cities during the age of the current pandemic (Covid-19). The data were collected during the months of January 2021 to February 2021. An English version of the questionnaire was employed to collect the responses from the banking personnel. Before the finalization of the instrument, the questionnaire was assessed by professionals from academia and the industry in order to establish whether the language of the questionnaire was simple and free from technical jargon or the words containing dual meanings. After the assessment and approval from the experts, the questionnaire was made available to the respondents to share their information. On a final note, the English language is a frequently used language in the banking sector of Pakistan, therefore, the authors foresaw no issue on the part of the respondents in answering the questionnaire.

Prior to the formal data collection process, the authors contacted the competent authorities of these banks to cooperate in the data collection process in the larger interest of academia and industry. In this regard, initial communication was made with the head offices of these banks. The authors also think it important to mention here the cooperation of the competent authorities of these banks in supporting the data collection process and providing formal permission to collect the data. The head offices indicated different branches situated in these cities for the sake of data collection. After receiving the formal permission for data collection, the authors then contacted the concerned branches to specify the schedule of data collection (dates and times). After going through all this process, finally, the authors were able to collect the data from banking personnel of the sampled banks. The sample data included both managers and non-managers who filled the printed version of the questionnaire (paper-pencil technique). The data collection process involved both managers/supervisors and the employees (non-managers). The data relating to employee creativity was obtained from the managers/supervisors whereas the employees were asked to rate their manager/supervisor for inclusive behavior. These guidelines can also be seen in the seminal work of Asif, Miao, Jameel, Manzoor and Hussain [23] and Asif, Qing, Hwang and Shi [5].

Additionally, the authors followed the significant ethical guidelines specified in the Helsinki Declaration [61]. In this regard, the respondents were assured that their shared information would be kept secret and would not be used for any other purpose beyond the scope of the current research. Further, each informant was served with an additional page seeking their informed consent to voluntarily participate in the data collection process. 
Furthermore, the participants were given the right to quit the information-giving process at any stage without specifying any reason if they felt uncomfortable disclosing any information. Finally, the authors disseminated 800 questionnaires (self-administered) to the banking personnel serving in different branches of these banks and received 533 filled questionnaires which were considered to be included in the final dataset. Thus, the response rate of the current survey remained close to $67 \%$ which is quite reasonable for the survey method of data collection through a questionnaire. The authors distributed 200 questionnaires in each bank. The details of true responses received from each bank are given in Table 1.

Table 1. Demographic detail.

\begin{tabular}{|c|c|c|}
\hline Demographic & Frequency $(n=533)$ & $\%$ \\
\hline \multicolumn{3}{|l|}{ Gender } \\
\hline Male & 322 & 56.89 \\
\hline Female & 211 & 43.11 \\
\hline \multicolumn{3}{|l|}{ Age-group (Year) } \\
\hline $22-25$ & 77 & 14.45 \\
\hline $26-30$ & 112 & 21.01 \\
\hline $31-35$ & 171 & 32.08 \\
\hline $36-40$ & 104 & 19.51 \\
\hline Above 40 & 69 & 12.94 \\
\hline \multicolumn{3}{|l|}{ Experience (Years) } \\
\hline $1-4$ & 84 & 15.76 \\
\hline $5-7$ & 192 & 36.02 \\
\hline $8-10$ & 154 & 28.90 \\
\hline Above 10 & 103 & 19.32 \\
\hline \multicolumn{3}{|l|}{ Category } \\
\hline Manager & 211 & 39.59 \\
\hline Non-Manager & 322 & 60.41 \\
\hline \multicolumn{3}{|l|}{ True responses } \\
\hline HBL & 137 & 25.70 \\
\hline NBP & 109 & 20.45 \\
\hline UBL & 129 & 24.21 \\
\hline ABL & 158 & 29.64 \\
\hline Total & 533 & 100 \\
\hline
\end{tabular}

\section{Instrument}

The process of instrumentation for the current survey considered already established scales to operationalize different constructs. In this regard, the authors were aligned with previous researchers who preferred already established scales to operationalize the different theoretical constructs, as these scales are reliable and valid to be pre-tested [62]. In this context, the construct of CSR was operationalized by employing the scale of Turker [63]. This is a famous scale to operationalize employees' CSR perceptions and is a widely used scale. In different instances, various researchers have used this scale in different contexts and cultures, for instance, Raza et al. [64] recently used the scale to tape employees' CSR perception in the hospitality sector of Pakistan. Similarly, it was used by Tian and Robertson [65] in the casino industry of China. The reliability value of this scale was $\alpha=0.92$. One sample item for this scale is "My bank participates in activities which aim to protect and improve the quality of the natural environment". There were a total of 12 items in this scale which were rated on a seven-point Likert scale.

Inclusive leadership was operationalized by using the scale of Carmeli, Reiter-Palmon and $\mathrm{Ziv}$ [25] which is also an established scale to tape the construct of inclusive leadership behavior. This scale is also used by extant researchers in different contexts. As an instance, 
Choi et al. [24] used this scale in the context of the service sector of Vietnam. In another instance, Qi, Liu, Wei and Hu [50] employed this scaled in the banking context of China. This scale was composed of nine items with a reliability value $\alpha=0.94$. The responses were collected on a seven-point Likert scale. A sample item of this scale is "my manager is attentive to new opportunities to improve work processes".

Finally, the authors used the scale of Coelho and Augusto [6] to measure the construct of employee creativity. This scale is also an established scale and has been used by different researchers. For instance, Hur, Moon and Ko [33], in their recent study, used this scale in the hotel sector of Korea. The scale is comprised of five items. A sample item is "I try to be as creative as I can in my job". A seven-point Likert scale was employed for the ratings of this construct. The reliability $\alpha=0.88$ showed a high level of reliability for this construct.

\section{Results and Analysis}

\subsection{Common Method Bias}

Given the fact that the current survey collected the data of the constructs from a single source, there is every possibility that the dataset of the current survey is confronted with a situation that gives rise to the potential issue of common method bias (CMB). The presence of $\mathrm{CMB}$ poses a strong possibility towards the establishment of false internal consistency. The authors, therefore, took different steps to minimize the issue of CMB; for instance, the anonymity of the participants was assured during the phase of data collection, this assurance is necessary for the respondents to give a genuine response. Likewise, the authors cross-verified the wording of each question to validate that there was no question with ambiguous or dual meanings. Similarly, the questions for a construct were randomly placed in the questionnaire without specifying any specific order. Although these procedural adjustments minimize the likelihood of CMB, the author performed a single-factor analysis proposed by Harman [66]. To do this, all the items were allowed to be loaded on a single factor to see whether the single factor explained a significant portion of the total variance (50\% or more) as per the guidelines of Podsakoff and Organ [67]. The outcomes of a single-factor analysis produced positive results as no single factor explained a significant variation. The maximum variation caused by the single factor was $40.28 \%$ in this context. Additionally, the authors also carried out a single confirmatory factor analysis (CFA) to further validate the presence of CMB. The outcomes of CFA indicated poor model fit indices values (MFI), implying that the single factor model poorly fits the actual (three-factor) model of the current survey $\left(\chi^{2}=3682.511, d f=421, \chi^{2} / d f=8.475\right.$, RMSEA $=0.099, \mathrm{CFI}=0.42, \mathrm{NFI}=0.40)$. Although these empirical steps were helpful to validate whether the issue of $\mathrm{CMB}$ was a potential risk or not, the authors employed the common latent factor (CLF) technique to further cement that there was no issue of CMB in the dataset of the current survey. CLF is considered as an advanced level technique to detect CMB as indicated by Podsakoff et al. [68] and further endorsed in the seminal work of Meade et al. [69] as one of the rigorous methods to detect CMB. To do this, the authors introduced a latent factor into the measurement model which was intended to affect all the items of each construct (i.e., CSR, IL, and EC). The CLF variance was constrained to ' 1 ' and the results revealed that the value of CMB was below the threshold level of 0.5, implying that CLF does not explain more than $50 \%$ of the total variance. Further, the authors used the regression estimates (standardized) of this model containing the latent factor to compare with the original measurement model without the latent factor. In this regard, the recommended value of 0.2 was assumed to be the cut-off value beyond which the issue of $\mathrm{CMB}$ was considered a potential threat as per the guidelines of Podsakoff, MacKenzie, Lee and Podsakoff [68]. To achieve this, first of all, the authors noted all the standardized regression estimates of the model with CLF and subtracted that from the model without any CLF (the original measured model). After performing this process, the authors noted the values of each item and found that no value was beyond 0.2 , establishing that there is no issue of CMB in the dataset of the current survey. 


\subsection{Construct Evaluation}

After verifying that the issue of $\mathrm{CMB}$ was no potential harm to the quality of the current dataset, the authors performed other different tests to establish the reliability and validity of the construct (Table 2). In this context, the authors validated convergent validity $(\mathrm{CnV})$ by calculating the average variance extracted (A.V.E) for each construct. The authors used the given formula to calculate A.V.E and followed the guidelines of Fornell and Larcker [70] and Gefen et al. [71] to validate $\mathrm{CnV}$ for each of the constructs. In the given formula, $\sum$ is the summation, $\lambda$ it the item loading and var is the error variance.

$$
\text { A.V.E }=\frac{\sum_{i=1}^{k} \lambda_{i}^{2}}{\sum_{i=1}^{k} \lambda_{i}^{2}+\sum_{i=1}^{k} \cdot \operatorname{var}(\varepsilon \mathbf{i})}
$$

Table 2. Factor loadings, convergent validity, and composite reliability.

\begin{tabular}{|c|c|c|c|c|c|c|c|}
\hline Item & $\Lambda$ & $\lambda^{2}$ & E-Variance & $\sum \lambda^{2}$ & Items & AVE & C.R \\
\hline $\begin{array}{l}\text { Our bank participates in activities that aim to protect and improve the } \\
\text { quality of the natural environment (CSR1) }\end{array}$ & 0.81 & 0.66 & 0.34 & & & & \\
\hline $\begin{array}{l}\text { Our bank makes investment to create a better life for the future } \\
\text { generations (CSR2) }\end{array}$ & 0.86 & 0.74 & 0.26 & & & & \\
\hline $\begin{array}{l}\text { Our bank implements special programs to minimize its negative impact on } \\
\text { the natural environment (CSR3) }\end{array}$ & 0.77 & 0.59 & 0.41 & & & & \\
\hline $\begin{array}{l}\text { Our bank targets a sustainable growth which considers to the future } \\
\text { generations (CSR4) }\end{array}$ & 0.73 & 0.53 & 0.47 & & & & \\
\hline $\begin{array}{l}\text { Our bank supports the non-governmental organizations working in the } \\
\text { problematic areas (CSR5) }\end{array}$ & 0.83 & 0.69 & 0.31 & & & & \\
\hline $\begin{array}{l}\text { Our bank contributes to the campaigns and projects that promote the } \\
\text { well-being of the society (CSR6) }\end{array}$ & 0.86 & 0.74 & 0.26 & & & & \\
\hline $\begin{array}{l}\text { Our bank encourages its employees to participate to the voluntarily } \\
\text { activities (CSR7) }\end{array}$ & 0.77 & 0.59 & 0.41 & & & & \\
\hline $\begin{array}{l}\text { Our bank policies encourage the employees to develop their skills and } \\
\text { careers (CSR8) }\end{array}$ & 0.82 & 0.67 & 0.33 & & & & \\
\hline $\begin{array}{l}\text { The management of our company primarily concerns with employees' } \\
\text { needs and wants (CSR9) }\end{array}$ & 0.89 & 0.79 & 0.21 & & & & \\
\hline $\begin{array}{l}\text { Our bank implements flexible policies to provide a good work and life } \\
\text { balance for its employees (CSR10) }\end{array}$ & 0.93 & 0.86 & 0.13 & & & & \\
\hline $\begin{array}{l}\text { The managerial decisions related with the employees are usually } \\
\text { fair (CSR11) }\end{array}$ & 0.86 & 0.74 & 0.26 & & & & \\
\hline $\begin{array}{l}\text { Our bank supports employees who want to acquire additional } \\
\text { education (CSR12) }\end{array}$ & 0.76 & 0.58 & 0.42 & 8.22 & 12 & 0.69 & 0.963 \\
\hline The manager is open to hearing new ideas (IL1) & 0.81 & 0.66 & 0.34 & & & & \\
\hline $\begin{array}{l}\text { The manager is attentive to new opportunities to improve work } \\
\text { processes (IL2) }\end{array}$ & 0.72 & 0.52 & 0.48 & & & & \\
\hline $\begin{array}{l}\text { The manager is open to discuss the desired goals and new ways to achieve } \\
\text { them (IL3) }\end{array}$ & 0.8 & 0.64 & 0.36 & & & & \\
\hline The manager is available for consultation on problems (IL4) & 0.83 & 0.69 & 0.31 & & & & \\
\hline $\begin{array}{l}\text { The manager is an ongoing 'presence' in this team-someone who is readily } \\
\text { available (IL5) }\end{array}$ & 0.87 & 0.76 & 0.24 & & & & \\
\hline $\begin{array}{l}\text { The manager is available for professional questions I would like to consult } \\
\text { with him/her (IL6) }\end{array}$ & 0.78 & 0.61 & 0.39 & & & & \\
\hline The manager is ready to listen to my requests (IL7) & 0.92 & 0.85 & 0.15 & & & & \\
\hline The manager encourages me to access him/her on emerging issues (IL8) & 0.88 & 0.77 & 0.23 & 6.41 & 9 & 0.71 & 0.956 \\
\hline The manager is accessible for discussing emerging problems (IL9) & 0.93 & 0.86 & 0.13 & & & & \\
\hline Employees here try to be as creative as they can (EC1) & 0.73 & 0.53 & 0.47 & & & & \\
\hline Employees experiment with new approaches in performing their job (EC2) & 0.82 & 0.67 & 0.33 & & & & \\
\hline $\begin{array}{l}\text { When new trends develop, employees are usually the first to get on } \\
\text { board (EC3) }\end{array}$ & 0.88 & 0.77 & 0.23 & & & & \\
\hline Employees think creatively in performing their job (EC4) & 0.79 & 0.62 & 0.38 & & & & \\
\hline Employees are inventive in overcoming barriers (EC5) & 0.72 & 0.52 & 0.48 & 3.12 & 5 & 0.62 & 0.892 \\
\hline
\end{tabular}

Notes: $\lambda=$ Item loadings, C.R = composite reliability, $\sum \lambda^{2}=$ sum of square of item loadings, E-Variance = error variance. 
To achieve this, the factor loadings (Table 2) of items related to a construct were used. The results of A.V.E were significant for each construct as all values of A.V.E were greater than 0.5 , implying that all the items of a construct converge on their respective factor and thus confirming the $\mathrm{CnV}$ for each construct.

Additionally, the authors performed a factor analysis to evaluate whether there was an issue in the factor loadings of an item (weak loading). The results of the factor analysis produced good enough results to establish that there was no issue in item loadings (all item loadings were beyond 0.7). The authors also validated the composite reliability (C.R) of each construct by employing the given formula and found that all values of C.R (greater than 0.7) were significant [72].

$$
\mathrm{C} \cdot \mathrm{R}=\frac{\left(\sum \lambda \mathrm{i}\right) 2}{\left(\sum \lambda \mathrm{i}\right) 2+\sum \operatorname{var}(\varepsilon \mathrm{i})}
$$

\subsection{Correlations and Discriminant Validity}

After the phase of construct evaluation, the authors carried out a correlation analysis and a discriminant validity (dVL) test. These results are reported in Table 3 for the readers. As one can see, the results of the correlation analysis were positive and significant, which implies that the constructs are positively correlated with one and other. For example, one can see that the value of correlation between IL and EC is $r=0.46^{* *}$ which is positive and significant. Further, the values of correlations are within the moderate ranges, implying that the issue of multicollinearity is not a potential threat in the case of the current dataset.

Table 3. Correlation, discriminant validity analysis.

\begin{tabular}{cccc}
\hline Construct & CSR & IL & EC \\
\hline CSR & 0.92 & $0.44^{* *}$ & $0.53^{* *}$ \\
IL & & 0.94 & $0.46^{* *}$ \\
EC & & & 0.88 \\
Mean & 6.22 & 6.13 & 5.99 \\
SD & 0.52 & 0.47 & 0.63 \\
MSV & 0.28 & 0.25 & 0.28 \\
ASV & 0.24 & 0.20 & 0.25 \\
\hline
\end{tabular}

Notes: S.D = standard deviation, ${ }^{* *}=$ significant values of correlation, bold diagonal = Cronbach alpha, maximum shared variance $=$ MSV, and average shared variance $=$ ASV.

The authors validated dVL for each construct by calculating the maximum-sharedvariance (M.S.V) and average-shared-variances (A.S.V) and comparing these values with A.V.E for a construct in comparison. For instance, the A.V.E value for EC $=0.62$ which is greater than MSV and ASV values $(0.28,0.25)$, and thus it is established that there is strong evidence of $d V L$. Therefore, it is statistically established that the items of each construct are different from the items of another construct, and thus they are diverging [73]. The authors performed a series of CFA for model-1 (single-factor), model-2, (two-factor), and model-3 (three-factor). These results are reported in Table 4 for the readers. As per the results of Table 4, model-3, which is the hypothesized model of the current study, produced the most significant results, as indicated by different MFI values. The results of the hypothesized model indicate that $\chi^{2} / d f$ was less than 0.3, which is desirable [74]. Likewise, both the values of CFI and NFI were significant as both produced values were greater than 0.9 [75]. Lastly, the value of RMSEA was below 0.06 [76]. All these values of MFIs validate the appropriateness of the hypothesized model. 
Table 4. Model fit comparison, alternate vs. hypothesized models.

\begin{tabular}{cccc}
\hline & Model-1 & Model-2 & Model-3 \\
\hline$\chi 2(d f)$ & $3682.51(421)$ & $3188.28(1089)$ & $2937.510(1309)$ \\
$\chi 2 / d f$ & 8.475 & 2.95 & 2.24 \\
NFI & 0.40 & 0.906 & 0.949 \\
CFI & 0.42 & 0.887 & 0.953 \\
RMSEA & 0.099 & 0.067 & 0.042 \\
SRMR & 0.099 & 0.069 & 0.043 \\
\hline
\end{tabular}

\subsection{Hypotheses Testing}

To validate the hypotheses of this analysis, the authors employed the structural equation modeling (SEM) technique using AMOS software. In this respect, the structural model was developed twice; first, the author tested the direct effect model to validate H1 and $\mathrm{H} 2$. At that point, there was no intervention of a mediator in the structural model. The results of the direct effect model are reported in Table 5 for the readers. According to these results, $\mathrm{H} 1$ and $\mathrm{H} 2$ were significant and positive $(\beta 1=0.293, \beta 2=0.316, p<0.05)$, as indicated by their respective beta values and $p$-values. Moreover, the upper limit confidence interval (ULCI) and lower limit confidence (LLCI) interval did not include a zero value; thus, $\mathrm{H} 1$ and $\mathrm{H} 2$ of the current study were statistically supported.

Table 5. The results for hypotheses testing $(\mathrm{H} 1, \mathrm{H} 2, \mathrm{H} 3)$.

\begin{tabular}{cccccccr}
\hline Path & Estimates & S.E & CR & $p$-Value & ULCI & LLCI & Decision \\
\hline CSR $\rightarrow$ EC & $(\beta 1) 0.293^{* *}$ & 0.0653 & 4.486 & $* * *$ & 0.429 & 0.313 & Accepted \\
CSR $\rightarrow$ IL & $(\beta 2) 0.482^{* *}$ & 0.0568 & 8.486 & $* * *$ & 0.382 & 0.197 & Accepted \\
IL $\rightarrow$ EC & $(\beta 3) 0.316^{* *}$ & 0.0692 & 4.566 & $* *$ & 0.367 & 0.219 & Accepted \\
\hline Notes: ULCI $=$ upper-limit confidence interval, LLCI $=$ lower-limit confidence interval, ${ }^{* * * * *},=$ significant values.
\end{tabular}

In the next level of the structural model, the authors included IL as a mediator and tested the results of $\mathrm{H} 3$ to validate whether the mediation effect is significant or not. To achieve this, the bootstrapping option in AMOS was employed and a large bootstrapping sample was used (2000). The outcomes of the mediated structural model proved that IL is a valid mediator between the relationship of CSR and EC $(\beta 3=0.152, p<0.05)$. Further, the mediation effect produced more than $34 \%$ of the variation in the construct of employee creativity. This effect of mediation was calculated by the given formula.

$$
\text { Proportion of mediation }=\frac{\text { Indirect effect }}{\text { Total effect }}
$$

Based on the above results, it is established that $\mathrm{H} 4$ of the current study is accepted. The mediation results for $\mathrm{H} 4$ are given in Table 6. Altogether, it is stated that $\mathrm{H} 1, \mathrm{H} 2, \mathrm{H} 3$, and $\mathrm{H} 4$ are supported.

Table 6. Mediation results for $\mathrm{H} 4$.

\begin{tabular}{cccccccc}
\hline Path & Estimates & S.E & Z-Score & $p$-Value & ULCI & LLCI & Decision \\
\hline $\mathrm{CSR} \rightarrow \mathrm{IL} \rightarrow \mathrm{EC}$ & $(\beta 4) 0.152 * *$ & 0.028 & 5.89 & $* * *$ & 0.218 & 0.162 & Supported \\
\hline
\end{tabular}

Notes: ULCI $=$ upper-limit confidence interval, $\mathrm{LLCI}=$ lower-limit confidence interval, ${ }^{* *},{ }^{* * *}=$ significant values, $\mathrm{S} . \mathrm{E}=$ standard error.

\section{Discussion and Implications}

There were two main objectives to carrying out this study: the first objective of the current survey was to explore the relationship between CSR and employee creativity in the banking sector of Pakistan. The findings of the current analysis confirm the positive association between employees' CSR perception of their organization and employee creativity. The authors think it very relevant here to explain these results in light of the social 
exchange theory. As mentioned earlier, social exchange theory posits that when individuals receive some benefit from others, they are expected to return this benefit positively. In other words, benefits are exchanged with benefits. In an organizational context, when an organization rewards its employees with benefits, it is likely that the employees will also return this benefit positively. Specifically, in the context of the current study, the CSR perception of employees for their organization is considered a kind of benefit for the community and society. As employees are also part of society, they welcome such CSR-related engagement of their organization. More specifically, from the perspective of employee creativity, CSR is a strategic enabler. The authors state this argument in a way that when employees observe that their organization is showing serious concern for the betterment of society and the community, they are self-convinced that their organization is performing an extra-role for society in the form of different CSR strategies. Thus, in line with social exchange theory, employees are also expected to support their organization by performing certain extra-roles, such as employee creativity. These lines of reasoning have also received support from recent researchers who proposed that CSR is an enabler for employee creativity $[32,77]$. Hence, the direct relationship between CSR and employee creativity was established in the banking context for the current study.

Another important objective of the current study was to establish the mediation effect of inclusive leadership between employees' perception of CSR and employee creativity in the banking sector of Pakistan. In this respect, the role of effective leadership in shaping employee behavior has already been established in the literature $[5,78,79]$. The authors argue here that although the direct relationship between leadership and employee behavior is evident in the existing literature, the mediating role of an effective leadership style, such as inclusive leadership, is very important to explain the relationship between CSR and employee creativity. The reason for this argument lies in the fact that the underlying mechanism of CSR and employee creativity has not reached a consensus yet. There have been different studies that produced contrasting results on the relationship between CSR and employee creativity compared to the results of the current study $[17,80]$. Thus, the reason to include some mediating constructs for the relationship between CSR and employee creativity is self-explanatory. In this respect, the findings of the current study validate that in the presence of an inclusive leader, the relationship between CSR and employee creativity is better explained because the leaders are in direct contact with their followers at the workplace. Therefore, as described earlier, an inclusive leader develops an environment of openness in an organization, thus employees are encouraged to come up with creative ideas to perform a task in a new and efficient manner. The results of the current study confirm a direct relationship between CSR and employee creativity, but in the presence of inclusive leadership as a mediating factor, a significant variation is caused by inclusive leadership (almost 35\%). Thus, the mediating effect of inclusive leadership is confirmed by the statistical findings of the current survey.

\subsection{Theoretical Implications}

The current study has some genuine contributions to theory and practice. To start with, the current study is one of the limited number of studies in the field of CSR that consider CSR to shape employee behavior, specifically their extra-role (creativity) behavior. Of direct importance to mention here is the fact that the majority of previous studies in the domain of CSR were conducted from an organizational perspective [81-83] and the CSR domain from the perspective of employees remains largely sparse. Therefore, the current study is an incremental attempt to bridging this gap. Another important addition of the current study to the available literature of leadership is that the relationship between effective leadership, such as ethical leadership $[23,84]$ and servant leadership $[85,86]$, to fostering employee creativity has already been established, however, the mediating effect of leadership, especially the effect of IL between CSR and employee creativity is not known.

Moreover, the current study adds to the creativity literature from the perspective of a developing economy (Pakistan), whereas prior studies were carried out in the context 
of the developed countries. The studies of Kremer et al. [87] and van Knippenberg and Hirst [88] are few recent examples in this regard. Therefore, the current study is one of those pioneering attempts to the field which attempt to bring forth the perspective of employee creativity from the standpoint of a developing country. Last but not the least, the current study adds to employee creativity literature from the perspective of the banking sector. To this end, previous studies did not consider this sector due to the fact that the banking sector is one that is run under a tight monitoring system, and thus creativity does not have a proper place in this sector. For example, see the recent studies conducted by Ma and Jiang [89] and Chaudhary and Akhouri [15]. Thus, the current study is one of the recent studies that document the importance of employee creativity for the banking sector.

\subsection{Practical Implications}

The practical implications of the current study for the banking sector are manifold. For example, the current study helps in improving the understanding of policymakers from banking institutions to consider CSR from the perspective of competitive advantage. The policymakers can enrich their understanding that well-planned CSR activities can offer a bank a solid base for sustainable competitive advantage. It is very relevant to mention here that the banking sector is one of those pioneering sectors in Pakistan where an established CSR framework is evident. However, CSR activities in this sector remained philanthropically oriented, for example, spending CSR funds on charity-related tasks, thus neglecting the importance of CSR in bringing competitive advantage to this industry. Another important practical implication of the current survey for the banking sector of Pakistan is that it introduces employees as a source of creativity. In this regard, it is mentioned here that generally the banking sector is assumed to be run with a set of standardized practices in which there is very litter room for creativity. Although, this observance to rules and regulation is evident in the overall banking industry in the world, some leading banks have acknowledged the importance of employees as a source of creativity and innovation and embraced the phenomenon of employee creativity as a "new normal" for this sector. The Standard Bank of South Africa is a classic example in which employees are encouraged to come up with creative ideas. In fact, the bank was able to solve its downtime ATM issue with the help of a creative idea shared by the employees. Other banks like Wells Fargo, Citigroup, Deutsche Bank, and Barclays have also initiated their in-house innovation labs in which employees are encouraged to share their creative ideas, implying that employee creativity is emerging as a "new normal" for this sector. In this regard, it is relevant to mention here that the management should give a special focus to employee training and development as a part of their value addition so that the employees may be able to equip themselves with the desired set of skills that can induce not only their formal job performance but also can contribute significantly to fostering their creative performance. These arguments can be seen in the work of Jyoti and Dev [90] and Yadav [91]. The CSR orientation of a bank in the context of training and development can provide additional support to the employees of a bank as a socially responsible bank considers facilitating the growth needs of its employees by providing different trainings and workshops which employees may find helpful to improve their creative capability [35]. Therefore, the management of a bank is suggested to facilitate the training component of the employees under the umbrella of CSR by understanding that a well-planned CSR orientation is not limited to the extent of charity, but it can also be used as a competitive advantage by supporting the employees through training and development. Thus, the current study shows that gone is the time when the banking sector and creativity were thought to be on two sides of a divide. Lastly, another practical contribution of the current study is that it brings the role of inclusive leadership to the fore to urge the employees to be involved in certain creative tasks while they are performing their job in a bank. To this end, the banking sector of Pakistan, in the past, was recognized for its tightly monitored environment in which the role of leadership was bureaucratic. Though over time, things 
have improved in this aspect, the current findings further cement the importance of a flexible leadership style to improving the extra-role behavior of employees.

\subsection{Limitations and Directions for Future}

This analysis also encountered some limitations which pave the way for future researchers in the field. For example, an important limitation of this analysis lies with the geographic concentration, as the data were collected only from two cities of the country. The authors have already explained that the data for the current survey were collected in the age of Covid-19 in which movement between different cities was not easy. In this respect, the authors propose to future researchers to include more cities in their sample to better generalize their results. Likewise, the cross-sectional nature of the data also limits the causality of the proposed relations; thus, for future researchers, it will be more appropriate to incorporate longitudinal data. Last but not least, this study attempts to explain employees' behavior, especially their extra-role behavior through CSR and an inclusive leadership style. Though the proposed relations (Figure 1) were significant, the authors still feel that human behavior is very complex to understand and explaining such complexity with the help of two variables may have specific consequences. Therefore, one suggestion for future researchers is to add more variables to the research model of the current study.

Author Contributions: Conceptualization, M.S.S. and C.W.; methodology, M.S.S.; software, M.S.S.; validation, M.S.S., C.W. and Z.U.; formal analysis, M.S.S.; investigation, M.S.S.; data curation, M.S.S.; writing-original draft preparation, M.S.S. and C.W.; writing-review and editing, M.S.S., C.W. and Z.U.; visualization, M.S.S.; supervision, C.W. This manuscript is part of M.S.S. Doctoral Dissertation. All authors have read and agreed to the published version of the manuscript.

Funding: This research received no external funding.

Institutional Review Board Statement: This study was carried out in accordance with the recommendations of the Academic Ethical Review Board of the Hefei University of Technology, Anhui, China. The protocol was approved by the Academic Ethical Review Board and Graduate School of the Hefei University of Technology, Anhui, China. All subjects participating in this research gave their written informed consent in accordance with the Declaration of Helsinki and were informed there was no knowing or anticipated risks associated with the participation in this research study and were reminded of their right that they may refuse to take part in the study or withdraw from the study at any time without jeopardizing their employment or any other rights before the survey. Prior to submitting this manuscript has been reviewed and approved in its final form by the Academic Ethical Review Board of the Hefei University of Technology, Anhui, China.

Informed Consent Statement: Informed consent was obtained from the respondents of the survey.

Data Availability Statement: The data will be made available on request from the corresponding author.

Acknowledgments: We appreciate the input from the editors and anonymous reviewers who contributed to improving the quality of this paper. The authors acknowledge Cisheng Wu for his guidance, support, and efforts during the evaluation and the publication process of this manuscript.

Conflicts of Interest: The authors declare no conflict of interest.

\section{References}

1. Skordoulis, M.; Ntanos, S.; Kyriakopoulos, G.L.; Arabatzis, G.; Galatsidas, S.; Chalikias, M. Environmental innovation, open innovation dynamics and competitive advantage of medium and large-sized firms. J. Open Innov. Technol. Mark. Complex. 2020, 6, 195. [CrossRef]

2. Drucker, P. Management: Tasks, Responsibilities, Practices; Collins Business: New York, NY, USA, 1993.

3. Na, Y.K.; Kang, S.; Jeong, H.Y. The effect of market orientation on performance of sharing economy business: Focusing on marketing innovation and sustainable competitive advantage. Sustainability 2019, 11, 729. [CrossRef]

4. Abdelmotaleb, M.; Mohamed Metwally, A.B.E.; Saha, S.K. Exploring the impact of being perceived as a socially responsible organization on employee creativity. Manag. Decis. 2018, 56, 2325-2340. [CrossRef]

5. Asif, M.; Qing, M.; Hwang, J.; Shi, H. Ethical leadership, affective commitment, work engagement, and creativity: Testing a multiple mediation approach. Sustainability 2019, 11, 4489. [CrossRef] 
6. Coelho, F.; Augusto, M. Job characteristics and the creativity of frontline service employees. J. Serv. Res. 2010, 13, 426-438. [CrossRef]

7. Ismail, H.N.; Iqbal, A.; Nasr, L. Employee engagement and job performance in Lebanon: The mediating role of creativity. Int. J. Product. Perform. Manag. 2019, 68, 506-523. [CrossRef]

8. Sarfraz, M.; Qun, W.; Abdullah, M.I.; Tahir, S. Authentic leadership, hope, work engagement and creativity. J. Appl. Manag. Invest. 2019, 8, 19-31.

9. Imam, H.; Naqvi, M.B.; Naqvi, S.A.; Chambel, M.J.J.L.; Journal, O.D. Authentic leadership: Unleashing employee creativity through empowerment and commitment to the supervisor. Leadersh. Organ. Dev. J. 2020, 41, 847-864. [CrossRef]

10. Tong, Z.; Zhu, L.; Zhang, N.; Livuza, L.; Zhou, N.J. Employees' perceptions of corporate social responsibility and creativity: Employee engagement as a mediator. Soc. Behav. Personal. Int. J. 2019, 47, 1-13. [CrossRef]

11. Scott, S.G.; Bruce, R.A. Determinants of innovative behavior: A path model of individual innovation in the workplace. Acad. Manag. J. 1994, 37, 580-607.

12. Kim, T.T.; Lee, G. Hospitality employee knowledge-sharing behaviors in the relationship between goal orientations and service innovative behavior. Int. J. Hosp. Manag. 2013, 34, 324-337. [CrossRef]

13. Volmer, J.; Spurk, D.; Niessen, C. Leader-member exchange (LMX), job autonomy, and creative work involvement. Leadersh. Q. 2012, 23, 456-465. [CrossRef]

14. Nazir, O.; Islam, J.U. Effect of CSR activities on meaningfulness, compassion, and employee engagement: A sense-making theoretical approach. Int. J. Hosp. Manag. 2020, 90, 102630. [CrossRef]

15. Chaudhary, R.; Akhouri, A. CSR perceptions and employee creativity: Examining serial mediation effects of meaningfulness and work engagement. Soc. Responsib. J. 2019, 15, 61-74. [CrossRef]

16. Ko, S.-H.; Choi, Y. The effect of CSR perception on creativity: The mediating effect of compassion and the moderating effect of CSR authenticity. J. Digit. Converg. 2020, 18, 59-70.

17. Mithani, M.A. Innovation and CSR-Do they go well together? Long Range Plan. 2017, 50, 699-711. [CrossRef]

18. Katz, D. The motivational basis of organizational behavior. Behav. Sci. 1964, 9, 131-146. [CrossRef]

19. Wallace, E.; de Chernatony, L.; Buil, I. Building bank brands: How leadership behavior influences employee commitment. J. Bus. Res. 2013, 66, 165-171. [CrossRef]

20. Carasco-Saul, M.; Kim, W.; Kim, T. Leadership and employee engagement: Proposing research agendas through a review of literature. Hum. Resour. Dev. Rev. 2015, 14, 38-63. [CrossRef]

21. Naile, I.; Selesho, J.M. The role of leadership in employee motivation. Mediterr. J. Soc. Sci. 2014, 5, 175. [CrossRef]

22. Madlock, P.E. The link between leadership style, communicator competence, and employee satisfaction. J. Bus. Commun. (1973) 2008, 45, 61-78. [CrossRef]

23. Asif, M.; Miao, Q.; Jameel, A.; Manzoor, F.; Hussain, A. How ethical leadership influence employee creativity: A parallel multiple mediation model. Curr. Psychol. 2020. [CrossRef]

24. Choi, S.B.; Tran, T.B.H.; Park, B.I.J. Inclusive leadership and work engagement: Mediating roles of affective organizational commitment and creativity. Soc. Behav. Personal. Int. J. 2015, 43, 931-943. [CrossRef]

25. Carmeli, A.; Reiter-Palmon, R.; Ziv, E.J. Inclusive leadership and employee involvement in creative tasks in the workplace: The mediating role of psychological safety. Creat. Res. J. 2010, 22, 250-260. [CrossRef]

26. Homans, G.C. Social behavior as exchange. Am. J. Sociol. 1958, 63, 597-606. [CrossRef]

27. Blau, P.M. Exchange and Power in Social Life; John Wiley and Sons. Inc.: New York, NY, USA, 2017.

28. Organ, D.W. Organizational Citizenship Behavior: The Good Soldier Syndrome; Lexington Books/DC Heath and Company: Lexington, MA, USA, 1988.

29. Afsar, B.; Cheema, S.; Javed, F. Activating employee's pro-environmental behaviors: The role of CSR, organizational identification, and environmentally specific servant leadership. Corp. Soc. Responsib. Environ. Manag. 2018, 25, 904-911. [CrossRef]

30. World Business Council for Sustainable Development Executive Committee. The Business case for sustainable development: Making a difference towards the Earth summit 2002 and beyond. Corp. Environ. Strategy 2002, 9, 226-235. [CrossRef]

31. Meseguer-Sánchez, V.; Gálvez-Sánchez, F.J.; López-Martínez, G.; Molina-Moreno, V. Corporate Social Responsibility and Sustainability. A Bibliometric Analysis of Their Interrelations. Sustainability 2021, 13, 1636. [CrossRef]

32. Chaudhary, R.; Akhouri, A. Linking corporate social responsibility attributions and creativity: Modeling work engagement as a mediator. J. Clean. Prod. 2018, 190, 809-821. [CrossRef]

33. Hur, W.-M.; Moon, T.-W.; Ko, S.-H. How employees' perceptions of CSR increase employee creativity: Mediating mechanisms of compassion at work and intrinsic motivation. J. Bus. Ethics 2018, 153, 629-644. [CrossRef]

34. Pandey, A.; Gupta, R.K. A perspective of collective consciousness of business organizations. J. Bus. Ethics 2008, 80, 889-898. [CrossRef]

35. Brammer, S.; He, H.; Mellahi, K. Corporate social responsibility, employee organizational identification, and creative effort: The moderating impact of corporate ability. Group Organ. Manag. 2015, 40, 323-352. [CrossRef]

36. Kim, B.-J.; Kim, M.-J.; Kim, T.-H. "The power of ethical leadership": The influence of corporate social responsibility on creativity, the mediating function of psychological safety, and the moderating role of ethical leadership. Int. J. Environ. Res. Public Health 2021, 18, 2968. [CrossRef] 
37. Bibi, S.; Khan, A.; Hayat, H.; Panniello, U.; Alam, M.; Farid, T. Do hotel employees really care for corporate social responsibility (CSR): A happiness approach to employee innovativeness. Curr. Issues Tour. 2021, 1-18. [CrossRef]

38. Nazir, O.; Islam, J.U. Influence of CSR-specific activities on work engagement and employees' innovative work behaviour: An empirical investigation. Curr. Issues Tour. 2020, 23, 3054-3072. [CrossRef]

39. Jones, D.A. Does serving the community also serve the company? Using organizational identification and social exchange theories to understand employee responses to a volunteerism programme. J. Occup. Organ. Psychol. 2010, 83, 857-878. [CrossRef]

40. Gouldner, A.W. The norm of reciprocity: A preliminary statement. Am. Sociol. Rev. 1960, 25, 161-178. [CrossRef]

41. Zhu, Y.; Sun, L.-Y.; Leung, A.S. Corporate social responsibility, firm reputation, and firm performance: The role of ethical leadership. Asia Pac. J. Manag. 2014, 31, 925-947. [CrossRef]

42. Vilkè, R.; Raišienè, A.G.; Simanavičienè, Ž. Gender and corporate social responsibility: 'big wins' for business and society? Procedia-Soc. Behav. Sci. 2014, 156, 198-202. [CrossRef]

43. Budur, T.; Demir, A. Leadership effects on employee perception about CSR in Kurdistan Region of Iraq. Int. J. Soc. Sci. Educ. Stud. 2019, 5, 184-192.

44. Pasricha, P.; Singh, B.; Verma, P. Ethical leadership, organic organizational cultures and corporate social responsibility: An empirical study in social enterprises. J. Bus. Ethics 2018, 151, 941-958. [CrossRef]

45. Guarnieri, R.; Kao, T. Leadership and CSR-a perfect match: How top companies for leaders utilize CSR as a competitive advantage. People Strategy 2008, 31, 34.

46. Visser, W. The nature of CSR leadership. Defin. Charact. Paradoxes. CSR Int. Pap. Ser. 2011, 4, 1-10.

47. Fang, Y.-C.; Ren, Y.-H.; Chen, J.-Y.; Chin, T.; Yuan, Q.; Lin, C.-L. Inclusive leadership and career sustainability: Mediating roles of supervisor developmental feedback and thriving at work. Front. Psychol. 2021, 12, 671663. [CrossRef] [PubMed]

48. Zeng, H.; Zhao, L.; Zhao, Y. Inclusive leadership and taking-charge behavior: Roles of psychological safety and thriving at work. Front. Psychol. 2020, 11, 62. [CrossRef]

49. Fang, Y.-C.; Chen, J.-Y.; Wang, M.-J.; Chen, C.-Y. The impact of inclusive leadership on employees' innovative behaviors: The mediation of psychological capital. Front. Psychol. 2019, 10, 1803. [CrossRef]

50. Qi, L.; Liu, B.; Wei, X.; Hu, Y. Impact of inclusive leadership on employee innovative behavior: Perceived organizational support as a mediator. PLoS ONE 2019, 14, e0212091. [CrossRef]

51. Nembhard, I.M.; Edmondson, A.C. Making it safe: The effects of leader inclusiveness and professional status on psychological safety and improvement efforts in health care teams. J. Organ. Behav. Int. J. Ind. Occup. Organ. Psychol. Behav. 2006, 27, 941-966. [CrossRef]

52. Hollander, E. Inclusive Leadership: The Essential Leader-Follower Relationship; Routledge: London, UK, 2012.

53. Randel, A.E.; Galvin, B.M.; Shore, L.M.; Ehrhart, K.H.; Chung, B.G.; Dean, M.A.; Kedharnath, U. Inclusive leadership: Realizing positive outcomes through belongingness and being valued for uniqueness. Hum. Resour. Manag. Rev. 2018, 28, 190-203. [CrossRef]

54. Ahmed, F.; Zhao, F.; Faraz, N.A. How and when does inclusive leadership curb psychological distress during a crisis? Evidence from the COVID-19 outbreak. Front. Psychol. 2020, 11, 1898. [CrossRef] [PubMed]

55. Zhao, F.; Ahmed, F.; Faraz, N.A. Caring for the caregiver during COVID-19 outbreak: Does inclusive leadership improve psychological safety and curb psychological distress? A cross-sectional study. Int. J. Nurs. Stud. 2020, 110, 103725. [CrossRef]

56. Boga, I.; Ensari, N. The role of transformational leadership and organizational change on perceived organizational success. Psychol.-Manag. J. 2009, 12, 235. [CrossRef]

57. Mastrangelo, A.; Eddy, E.R.; Lorenzet, S.J. The relationship between enduring leadership and organizational performance. Leadersh. Organ. Dev. J. 2014, 35, 590-604. [CrossRef]

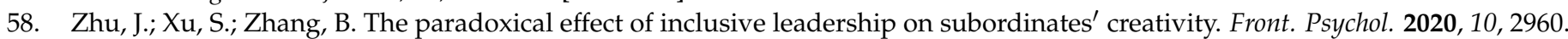
[CrossRef]

59. Chen, Y.-R.R.; Hung-Baesecke, C.-J.F. Examining the internal aspect of corporate social responsibility (CSR): Leader behavior and employee CSR participation. Commun. Res. Rep. 2014, 31, 210-220. [CrossRef]

60. The News. Islamic Banks' Market Share Up. Available online: https:/ /www.thenews.com.pk (accessed on 28 April 2021).

61. Declaration, H. Human experimentation: Code of ethics of World Medical Association Br. Br. Med. J. $1964,2,18$.

62. Hyman, L.; Lamb, J.; Bulmer, M. The use of pre-existing survey questions: Implications for data quality. In Proceedings of the European Conference on Quality in Survey Statistics, Cardiff, Wales, UK, 24 April 2006; pp. 1-8.

63. Turker, D. Measuring corporate social responsibility: A scale development study. J. Bus. Ethics 2009, 85, 411-427. [CrossRef]

64. Raza, A.; Farrukh, M.; Iqbal, M.K.; Farhan, M.; Wu, Y. Corporate social responsibility and employees' voluntary pro-environmental behavior: The role of organizational pride and employee engagement. Corp. Soc. Responsib. Environ. Manag. 2021, 28, 1104-1116. [CrossRef]

65. Tian, Q.; Robertson, J.L. How and when does perceived CSR affect employees' engagement in voluntary pro-environmental behavior? J. Bus. Ethics 2019, 155, 399-412. [CrossRef]

66. Harman, H.H. Modern Factor Analysis; University of Chicago press: Chicago, IL, USA, 1976.

67. Podsakoff, P.M.; Organ, D.W. Self-reports in organizational research: Problems and prospects. J. Manag. 1986, 12, 531-544. [CrossRef] 
68. Podsakoff, P.M.; MacKenzie, S.B.; Lee, J.-Y.; Podsakoff, N.P. Common method biases in behavioral research: A critical review of the literature and recommended remedies. J. Appl. Psychol. 2003, 88, 879. [CrossRef]

69. Meade, A.W.; Watson, A.M.; Kroustalis, C.M. Assessing common methods bias in organizational research. In Proceedings of the 22nd Annual Meeting of the Society for Industrial and Organizational Psychology, New York, NY, USA, 27 April 2007; pp. 1-10.

70. Fornell, C.; Larcker, D.F. Evaluating structural equation models with unobservable variables and measurement error. J. Mark. Res. 1981, 18, 39-50. [CrossRef]

71. Gefen, D.; Straub, D.; Boudreau, M.-C. Structural equation modeling and regression: Guidelines for research practice. Commun. Assoc. Inf. Syst. 2000, 4, 7. [CrossRef]

72. Qing, M.; Asif, M.; Hussain, A.; Jameel, A.J. Exploring the impact of ethical leadership on job satisfaction and organizational commitment in public sector organizations: The mediating role of psychological empowerment. Rev. Manag. Sci. 2020, 14, 1405-1432.

73. Hair, J.; Anderson, R.; Babin, B.; Black, W. Multivariate Data Analysis: A Global Perspective; Pearson: Upper Saddle River, NJ, USA, 2010.

74. Asif, M.; Jameel, A.; Hussain, A.; Hwang, J.; Sahito, N. Linking transformational leadership with nurse-assessed adverse patient outcomes and the quality of care: Assessing the role of job satisfaction and structural empowerment. Int. J. Environ. Res. Public Health 2019, 16, 2381. [CrossRef] [PubMed]

75. Iacobucci, D. Structural equations modeling: Fit indices, sample size, and advanced topics. J. Consum. Psychol. 2010, 20, 90-98. [CrossRef]

76. Hair, J.; Black, W.; Babin, B.; Anderson, R. Multivariate Data Analysis; Pearson Education Limited: Harlow, UK, 2014 ; pp. 1-292.

77. Chaudhary, R. Corporate social responsibility and employee performance: A study among indian business executives. Int. J. Hum. Resour. Manag. 2020, 31, 2761-2784. [CrossRef]

78. Yao, Y.-H.; Fan, Y.-Y.; Guo, Y.-X.; Li, Y. Leadership, work stress and employee behavior. Chin. Manag. Stud. 2014, 8, 109-126. [CrossRef]

79. Graves, L.M.; Sarkis, J.; Zhu, Q. How transformational leadership and employee motivation combine to predict employee proenvironmental behaviors in China. J. Environ. Psychol. 2013, 35, 81-91.

80. Gallego-Álvarez, I.; Manuel Prado-Lorenzo, J.; García-Sánchez, I.M. Corporate social responsibility and innovation: A resourcebased theory. Manag. Decis. 2011, 49, 1709-1727. [CrossRef]

81. Al-Samman, E.; Al-Nashmi, M.M. Effect of corporate social responsibility on nonfinancial organizational performance: Evidence from Yemeni for-profit public and private enterprises. Soc. Responsib. J. 2016, 12, 247-262. [CrossRef]

82. Franco, S.; Caroli, M.G.; Cappa, F.; Del Chiappa, G. Are you good enough? CSR, quality management and corporate financial performance in the hospitality industry. Int. J. Hosp. Manag. 2020, 88, 102395. [CrossRef]

83. Mohamed, M.S.; Anisa, H. Establishing the link of OCB and CSR with organizational performance. J. Manag. Res. 2014, 14, 143-158.

84. Duan, S.; Liu, Z.; Che, H. Mediating influences of ethical leadership on employee creativity. Soc. Behav. Personal. Int. J. 2018, 46, 323-337. [CrossRef]

85. Ahmad, N.; Scholz, M.; Arshad, M.Z.; Jafri, S.K.A.; Sabir, R.I.; Khan, W.A.; Han, H. The inter-relation of corporate social responsibility at employee level, servant leadership, and innovative work behavior in the time of crisis from the healthcare sector of pakistan. Int. J. Environ. Res. Public Health 2021, 18, 4608. [CrossRef]

86. Wang, Z.; Guan, C.; Cui, T.; Cai, S.; Liu, D. Servant leadership, team reflexivity, coworker support climate, and employee creativity: A multilevel perspective. J. Leadersh. Organ. Stud. 2021. [CrossRef]

87. Kremer, H.; Villamor, I.; Aguinis, H. Innovation leadership: Best-practice recommendations for promoting employee creativity, voice, and knowledge sharing. Bus. Horiz. 2019, 62, 65-74. [CrossRef]

88. van Knippenberg, D.; Hirst, G. A motivational lens model of person $\times$ situation interactions in employee creativity. J. Appl. Psychol. 2020, 105, 1129. [CrossRef]

89. Ma, X.; Jiang, W. Transformational leadership, transactional leadership, and employee creativity in entrepreneurial firms. J. Appl. Behav. Sci. 2018, 54, 302-324. [CrossRef]

90. Jyoti, J.; Dev, M. The impact of transformational leadership on employee creativity: The role of learning orientation. J. Asia Bus. Stud. 2015, 9, 78-98. [CrossRef]

91. Yadav, A. Linking potential training outcomes to employee creativity in retailing: A systems view. Amity J. Train. Dev. 2016, 1, 32-35. 